NANAEKE

Indonesian Journal of Early Childhood Education

Volume 4, Nomor 2, Desember 2021

\title{
PENGGUNAAN NYANYIAN UNTUK MENINGKATKAN PERKEMBANGAN BAHASA ANAK SPEECH DELAY
}

\author{
Nur Ardianti \\ Jurusan Pendidikan Islam Anak Usia Dini \\ Fakultas Tarbiyah dan Keguruan, UIN Alauddin Makassar \\ e-mail: nurardianti80@gmail.com \\ Umi Kusyairy \\ Jurusan Pendidikan Islam Anak Usia Dini \\ Fakultas Tarbiyah dan Keguruan, UIN Alauddin Makassar \\ e-mail: Umi.kusyairi@uin-alauddin.ac.id \\ M. Yusuf Tahir \\ Jurusan Pendidikan Islam Anak Usia Dini \\ Fakultas Tarbiyah dan Keguruan, UIN Alauddin Makassar \\ e-mail: yustarzef@gmail.com
}

\begin{abstract}
Abstrak
Penelitian ini bertujuan untuk membahas tentang: (1) bagaimana perkembangan bahasa anak speech delay sebelum penggunaan nyanyian; (2) bagaimana perkembangan bahasa anak speech delay setelah penggunaan nyanyian; (3) apakah terdapat peningkatan perkembangan bahasa sebelum dan sesudah penggunaan nyanyian terhadap anak speech delay. Penelitian dengan metode eksperimen ini menggunakan jenis penelitian subjek tunggal (single subject research) dengan desain penelitian A-B-A. Objek dalam penelitian ini, yaitu perkembangan bahasa anak speech delay dengan jumlah sampel yaitu satu orang (AR). Hasil Penelitian menunjukkan bahwa: (1) perkembangan bahasa anak speech delay sebelum penggunaan nyanyian sebanyak 19 kata (kategori belum meningkat); (2) perkembangan bahasa anak speech delay setelah penggunaan nyanyian sebanyak 82 kata (kategori meningkat meskipun termasuk rendah untuk anak seusianya); (3) terdapat peningkatan perkembangan bahasa sebelum dan setelah penggunan nyanyian terhadap anak speech delay, dimana AR memperoleh kosakata sebanyak 108 kata setelah evaluasi (kategori meningkat).
\end{abstract}

Kata Kunci: Penggunaan Nyanyian, Perkembangan Bahasa, Speech Delay

\section{Abstract}

This research aims to discuss: (1) the language development of speech delay children before the use of singing; (2) the language development of speech delay children after the use of singing; (3) an increase in language development before and after the use of singing on speech delay children. This experimental method research used single-subject research with 
research design $A-B-A$. The object in this study, namely the development of the children's language speech delay with one person $(A R)$ as a sample. The results showed that: (1) the language development of speech delay children before the use of singing was 19 words (the category not increased); (2) the language development of speech delay children after the use of singing were 82 words (the category increased even though it is low for his age); (3) there is an increase in language development before and after the use of singing in speech delay children, where AR obtained a vocabulary of 108 words after the evaluation ((the category increased).

Keywords: Use of Singing, Languaged Development, Speech Delay

\section{PENDAHULUAN}

Pendidikan diartikan oleh Ki Hajar Dewantara sebagai daya dan upaya untuk memajukan budi pekerti, pikiran serta jasmani dari anak agar mendukung kesempurnaan hidup, yakni membantu hidup dan menghidupkan anak yang senada dengan kondisi faktual alam dan kemajemukan masyarakat, dimanapun anak berada (Nurkholis, 2013). Pedagogik yang diartikan sebagai pendidikan berasal dari bahasa Yunani yang bermakna ilmu untuk menuntun anak. Dahulu, keturunan bangsa Yunani maupun Romawi mendeskripsikan pendidikan sebagai bagian dari educare, yaitu proses menuntun yang disertai dengan aneka tindakan untuk merealisasikan potensi milik anak yang dibawanya ketika ditakdirkan untuk lahir dan menjalani kehidupan di dunia (Herlambang, 2018 dan Rasyidin, 2014). Selanjutnya bangsa Jerman mendeskripsikan pendidikan sebagai bagian dari Erziehung (Nutbrown dan Clough, 2015). Hal ini sesuai dengan educare, yakni proses mengaktifkan potensi milik anak yang tersimpan di dalam dirinya (Irwantoro, Suryana, Rohmah, dan Nazim, 2016). Adapun dalam etimiologi suku Jawa, pendidikan disebut sebagai panggulawentah atau proses pengubahan kondisi psikologis berupa aspek perasaan, kemauan, pikiran, serta watak yang dilakukan secara bertahap untuk menyusun struktur dari kepribadian seorang anak (Tilaar, 2015).

Kemendikbud memaparkan bahwa tujuan Pendidikan Anak Usia Dini (PAUD) menurut Undang-Undang Nomor 20 tahun 2003 tentang sistem pendidikan nasional dinyatakan bahwa pendidikan anak usia dini adalah sebagai suatu upaya pembinaan yang ditujukan kepada anak sejak lahir hingga anak berusia enam tahun (Suyadi, 2013). Hal ini dilakukan melalui pemberian rangsangan pendidikan untuk membantu pertumbuhan dan perkembangan jasmani dan rohani agar anak mempunyai kesiapan dalam memasuki pendidikan ke jenjang selanjutnya (Fauziddin dan Mufarizuddin, 2018). Hal ini di dukung oleh Permendikbud Nomor 37 tahun 2014 (Suminah, Nugraha, Yusuf, Puspita, dan Soendjojo, 2018) yang menjelaskan bahwa pendidikan anak usia dini merupakan pendidikan yang ditujukan untuk anak usia dini dalam rangka memaksimalkan aspek-aspek 
perkembangannya. Terdapat enam aspek perkembangan yang harus dikembangkan oleh guru Pendidikan Anak Usia Dini (PAUD). Keenam aspek tersebut adalah aspek perkembangan nilai agama dan moral, fisik-motorik kognitif, bahasa, sosial-emosional, dan seni (Latif, Zukhairina, Zubaidah, dan Afandi, 2013). Khusus pada aspek perkembangan bahasa anak mencakup (Sujiono, 2013): (1) memahami bahasa reseptif, seperti mampu memahami cerita, aturan, perintah, menghargai dan menyenangi bacaan; (2) mengekspresikan bahasa, seperti mampu bertanya dan menjawab pertanyaan, berkomunikasi lisan, menceritakan kembali hal yang diketahui, mempelajari bahasa pragmatik, mengekspresikan ide, perasaan, dan keinginan berbentuk coretan; dan (3) keaksaraan, seperti pemahaman pada hubungan bentuk dan bunyi huruf, menirukan bentuk huruf, juga memahami kata di dalam cerita.

Lestari (2016) mengatakan perkembangan bahasa pada anak usia dini sangat penting karena dengan bahasa sebagai dasar kemampuan, seorang anak akan dapat meningkatkan kemampuan-kemampuan yang lain. Morrison (2012) berpendapat bahwa para pendidik sebaiknya senantiasa memperhatikan perkembangan dari para peserta didiknya yang merupakan anak-anak usia dini, karena pada masa usia dini inilah yang sangat menentukan keberlansungan dari proses belajar pada tingkat selanjutnya. Pendidik perlu menerapkan ide-ide yang dimilikinya untuk mengembangkan kemampuan berbahasa anak misalnya dengan strategi bermain kartu huruf dan bernyanyi yang bertujuan mengembangkan bahasa anak dan penggunaan beragam media-media yang mendukung pembelajaran bahasa (Madyawati, 2017).

Adapun terkait dengan perkembangan bahasa anak, dewasa ini semakin banyak ditemukan anak usia dini yang mengalami keterlambatan dalam berbicara. Umah (2018) menjelaskan bahwa keterlambatan bicara (speech delay) adalah salah satu penyebab gangguan perkembangan dalam berbahasa anak. Istilah speech delay yang dialami oleh anak usia dini menunjukkan ketidaknormalan atas kemampuan berbicara anak usia dini tersebut jika dibandingkan dengan kemampuan anak yang seusianya, seperti pada saat teman sebayanya mampu berbicara menggunakan kata-kata yang tepat (Usman, 2015). Sedangkan anak dengan speech delay terus menggunakan isyarat dan gaya bicara seperti bayi sehingga menambah kecemasan dari para orangtua terkait dengan proses tumbuh kembangnya kelak (Tsuraya. 2013). Anak dengan speech delay dapat tetap mengikuti pola tumbuh kembang yang normal, tetapi jauh lebih lambat dari ratarata teman yang sebayanya (Yasin, Aksu, Özgür, dan Özgür, 2017). Jika speech delay ini tidak segera diatasi dengan tepat, maka akan terjadi gangguan kognitif, yaitu gangguan kemampuan membaca, gangguan kemampuan verbal, gangguan perilaku, gangguan penyesuaian psikososial, dan kurangnya kemampuan akademis (Puspita, Perbawani, Adriyanti, dan Sumarlam. 2019). 


\section{METODE PENELITIAN}

Jenis penelitian yang digunakan adalah penelitian eksperimen dengan subjek tunggal atau Single Subject Research (SSR). Desain penelitian yang digunakan adalah desain A-B-A (Saat dan Mania, 2018). Sampel dalam penelitian ini merupakan anak berusia 5 tahun yang terdiri dari satu orang atau single subjek (Otto, 2015). Observasi dan wawancara awal pada 11 September 2019 dengan Ibu AS, guru dari sampel penelitian yang bernama AR di sekolah $\mathrm{X}$ yang menunjukkan bahwa AR mengalami speech delay, tanpa adanya kepedulian orangtua dan lingkungan sekitar yang terkesan membiarkan AR menggunakan bahasa yang belum fasih seperti penyebutan kata 'au amma' ketika AR ingin makan. Sehingga, peneliti termotivasi untuk melakukan penelitian ini. Adapun teknik pengumpulan data yang digunakan adalah observasi dan dokumentasi yang diadaptasi dari Madyawati (2017) dan Hutami dan Samsidar (2018).

\section{HASIL DAN PEMBAHASAN}

Tabel 1. Penggunaan Nyanyian untuk Meningkatkan Perkembangan

$$
\text { Bahasa Anak Speech Delay }
$$

\begin{tabular}{|c|c|c|c|c|c|}
\hline \multirow{2}{*}{ No } & \multirow{2}{*}{ Indikator } & \multirow{2}{*}{ Target Capaian } & \multicolumn{3}{|c|}{ Narasi } \\
\hline & & & Baseline A1 & Intervensi B & Baseline A2 \\
\hline 1. & $\begin{array}{l}\text { Menyimak } \\
\text { Perkataan } \\
\text { peneliti }\end{array}$ & $\begin{array}{l}\text { Mengucapkan } \\
\text { terima kasih dan } \\
\text { mohon maaf }\end{array}$ & $\begin{array}{l}\text {-AR } \\
\text { mengucapkan } \\
\text { eima asih dan } \\
\text { oon maa } \\
\text { sesuai yang } \\
\text { diucapkan } \\
\text { peneliti }\end{array}$ & $\begin{array}{l}\text {-telima } \\
\text { kasihku, moon } \\
\text { maaf }\end{array}$ & $\begin{array}{l}\text {-telima kasih } \\
\text { moon maaf }\end{array}$ \\
\hline 2. & $\begin{array}{l}\text { Mengenal suara- } \\
\text { suara } \\
\text { hewan/benda }\end{array}$ & $\begin{array}{l}\text { Menirukan } \\
\text { suara kucing, } \\
\text { sapi, ayam, } \\
\text { kambing, }\end{array}$ & $\begin{array}{l}\text {-AR meniru } \\
\text { suara eong, } \\
\text { mooo, } \\
\text { kukuruyu, } \\
\text { mbee }\end{array}$ & $\begin{array}{l}\text {-meong- } \\
\text { meong, mooo, } \\
\text { kukuruyu, } \\
\text { mbee. }\end{array}$ & $\begin{array}{l}\text {-AR } \\
\text { menirukan } \\
\text { suara kucing, } \\
\text { sapi, ayam } \\
\text { dan kambing } \\
\text { dengan } \\
\text { benar }\end{array}$ \\
\hline 3. & $\begin{array}{l}\text { Menjawab } \\
\text { pertanyaan } \\
\text { sesuai } \\
\text { pertanyaan }\end{array}$ & $\begin{array}{l}\text { Menjawab } \\
\text { pertanyaan } \\
\text { peneliti AR } \\
\text { sudah makan }\end{array}$ & $\begin{array}{l}\text {-AR belum } \\
\text { tahu ketika } \\
\text { ditanya sudah } \\
\text { makan atau } \\
\text { belum }\end{array}$ & $\begin{array}{l}\text {-AR mulai } \\
\text { memahami } \\
\text { pertanyaan } \\
\text { peneliti } \\
\text { dengan kata ia }\end{array}$ & $\begin{array}{l}\text {-AR } \\
\text { menjawab } \\
\text { pertanyaan } \\
\text { pertanyaan } \\
\text { peneliti } \\
\text { dengan } \\
\text { menjawab ia } \\
\text { sudah }\end{array}$ \\
\hline 4. & Mengerti & Mampu & -AR sudah & -AR mampu & -AR mampu \\
\hline
\end{tabular}

92 NANAEKE - Indonesian Journal of Early Childhood Education, Vol. 4, No. 2, Desember 2021 


\begin{tabular}{|c|c|c|c|c|c|}
\hline & $\begin{array}{l}\text { beberapa } \\
\text { perintah secara } \\
\text { bersamaan }\end{array}$ & $\begin{array}{l}\text { melakukan } \\
\text { perintah peneliti } \\
\text { AR sudah bisa } \\
\text { menggambar } \\
\text { rumah dan } \\
\text { menulis } \\
\text { namanya }\end{array}$ & $\begin{array}{l}\text { bisa } \\
\text { menggambar } \\
\text { dengan } \\
\text { bantuan } \\
\text { peneliti tapi } \\
\text { belum bisa } \\
\text { memberikan } \\
\text { nama pada } \\
\text { yang di } \\
\text { gambar. }\end{array}$ & $\begin{array}{l}\text { menggambar, } \\
\text { menuliskan } \\
\text { dan } \\
\text { memberikan } \\
\text { nama pada } \\
\text { gambar } \\
\text { "rumah AR }\end{array}$ & $\begin{array}{l}\text { menggambar, } \\
\text { menulis dan } \\
\text { memberikan } \\
\text { nama pada } \\
\text { gambar } \\
\text { "rumah AR. }\end{array}$ \\
\hline 5. & $\begin{array}{l}\text { Mengulang } \\
\text { kalimat yang } \\
\text { lebih kompleks }\end{array}$ & $\begin{array}{l}\text { AR mengulang } \\
\text { kalimat "pagiku } \\
\text { cerahku } \\
\text { matahari } \\
\text { bersinar" sesuai } \\
\text { yang diucapkan } \\
\text { peneliti }\end{array}$ & $\begin{array}{l}\text {-AR belum } \\
\text { mampu } \\
\text { mengucapkan } \\
\text { kalimat } \\
\text { "pagiku } \\
\text { cerahku" } \\
\text { yang } \\
\text { diucapkan } \\
\text { peneliti }\end{array}$ & $\begin{array}{l}\text {-AR sudah } \\
\text { mampu } \\
\text { mengucapkan } \\
\text { kalimat } \\
\text { "pagiku } \\
\text { cerahku" }\end{array}$ & $\begin{array}{l}\text {-AR mampu } \\
\text { menyanyikan } \\
\text { dan } \\
\text { menyebutkan } \\
\text { kalimat } \\
\text { "pagiku } \\
\text { cerahku } \\
\text { matahari, ku } \\
\text { gendong tas } \\
\text { merahku di } \\
\text { pundak" } \\
\text { dengan } \\
\text { benar }\end{array}$ \\
\hline 6. & $\begin{array}{l}\text { Memahami } \\
\text { aturan dalam } \\
\text { bernyanyi }\end{array}$ & $\begin{array}{l}\text { AR mengikuti } \\
\text { kegiatan } \\
\text { bernyanyi dan } \\
\text { bertepuk tangan } \\
\text { sambil berputar- } \\
\text { putar }\end{array}$ & $\begin{array}{l}\text {-AR mengikuti } \\
\text { kegiatan } \\
\text { bernyanyi } \\
\text { dengan tema } \\
\text { lagu "terima } \\
\text { kasih guruku" } \\
\text { hanya } \\
\text { mampu } \\
\text { menyebutkan } \\
\text { "pagiku } \\
\text { cerahku } \\
\text { matahari } \\
\text { bersinar ku } \\
\text { gendong tas } \\
\text { merahku } \\
\text { dipundak" } \\
\text { sambil } \\
\text { bertepuk } \\
\text { tangan } \\
\text { dengan } \\
\text { bantuan }\end{array}$ & $\begin{array}{l}\text {-AR mampu } \\
\text { menyebutkan } \\
\text { lirik lagu } \\
\text { “pagiku } \\
\text { cerahku } \\
\text { matahari } \\
\text { bersinar ku } \\
\text { gendong tas } \\
\text { merahku } \\
\text { dipundak, } \\
\text { selamat pagi } \\
\text { semua ku } \\
\text { nantikan } \\
\text { dirimu di } \\
\text { depan } \\
\text { kelasmu } \\
\text { nantikan } \\
\text { kami” dengan } \\
\text { tepuk tangan }\end{array}$ & $\begin{array}{l}\text {-AR sudah } \\
\text { mampu } \\
\text { mengikuti } \\
\text { lirik lagu } \\
\text { “pagiku } \\
\text { cerahku } \\
\text { matahari } \\
\text { bersinar ku } \\
\text { gendong tas } \\
\text { merahku } \\
\text { dipundak } \\
\text { selamat pagi } \\
\text { semua ku } \\
\text { nantikan } \\
\text { dirimu di } \\
\text { depan } \\
\text { kelasmu } \\
\text { nantikan } \\
\text { kami” } \\
\text { dengan } \\
\text { benar }\end{array}$ \\
\hline
\end{tabular}




\begin{tabular}{|c|c|c|c|c|c|}
\hline & & & peneliti & & \\
\hline 7. & $\begin{array}{l}\text { Senang } \\
\text { mendengarkan } \\
\text { kegiatan } \\
\text { bernyanyi }\end{array}$ & $\begin{array}{l}\text { AR senang } \\
\text { ketika } \\
\text { dinyanyiakan } \\
\text { sebuah lagu } \\
\text { terima kasih } \\
\text { guruku diiringi } \\
\text { video musik }\end{array}$ & $\begin{array}{l}\text {-AR mengikuti } \\
\text { kegiatan } \\
\text { nyanyian yang } \\
\text { diperlihatkan } \\
\text { oleh peneliti }\end{array}$ & $\begin{array}{l}\text {-AR mampu } \\
\text { mengikuti } \\
\text { nyanyian dan } \\
\text { menyebutkan } \\
\text { lirik lagu } \\
\text { "pagiku } \\
\text { cerahku } \\
\text { matahari } \\
\text { bersinar ku } \\
\text { gendong tas } \\
\text { merahku } \\
\text { dipundak, } \\
\text { selamat pagi } \\
\text { semua ku } \\
\text { nantikan } \\
\text { dirimu di } \\
\text { depan } \\
\text { kelasmu } \\
\text { menantikan } \\
\text { kami, guruku } \\
\text { tersayang } \\
\text { guruku } \\
\text { tercinta, } \\
\text { tanpamu apa } \\
\text { jadinya aku” } \\
\text { dengan } \\
\text { bantuan guru }\end{array}$ & $\begin{array}{l}\text {-AR mampu } \\
\text { mengikuti } \\
\text { dan } \\
\text { menyebutkan } \\
\text { lirk lagu } \\
\text { "pagiku } \\
\text { cerahku } \\
\text { matahari } \\
\text { bersinar ku } \\
\text { gendong tas } \\
\text { merahku } \\
\text { dipundak, } \\
\text { selamat pagi } \\
\text { semua ku } \\
\text { nantikan } \\
\text { dirimu di } \\
\text { depan } \\
\text { kelasmu } \\
\text { menantikan } \\
\text { kami, guruku } \\
\text { tersayang } \\
\text { guruku } \\
\text { tercinta, } \\
\text { tanpamu apa } \\
\text { jadinya aku" } \\
\text { dengan } \\
\text { bantuan } \\
\text { peneliti. }\end{array}$ \\
\hline 8. & $\begin{array}{l}\text { Mengenal lirik } \\
\text { lagu dan } \\
\text { menyebutkan }\end{array}$ & $\begin{array}{l}\text { Mengenal lirik } \\
\text { lagu "terima } \\
\text { kasih guruku" } \\
\text { dan } \\
\text { menyebutkan }\end{array}$ & $\begin{array}{l}\text {-AR mampu } \\
\text { menyebutkan } \\
\text { judul lagu } \\
\text { setelah } \\
\text { diputarkan } \\
\text { musik yaitu } \\
\text { "terima kasih } \\
\text { guruku". }\end{array}$ & $\begin{array}{l}\text {-AR sudah } \\
\text { mampu } \\
\text { mengenal lirik } \\
\text { lagu “terima } \\
\text { kasih guruku” } \\
\text { dan } \\
\text { menyebutkan } \\
\text { "pagiku } \\
\text { cerahku } \\
\text { matahari } \\
\text { bersinar ku } \\
\text { gendong tas } \\
\text { merahku } \\
\text { dipundak, } \\
\text { selamat pagi }\end{array}$ & $\begin{array}{l}\text {-AR mampu } \\
\text { menebak lirik } \\
\text { lagu dan } \\
\text { menyebutkan } \\
\text { lirik lagu } \\
\text { “pagiku } \\
\text { cerahku } \\
\text { matahari } \\
\text { bersinar ku } \\
\text { gendong tas } \\
\text { merahku } \\
\text { dipundak, } \\
\text { selamat pagi } \\
\text { semua ku } \\
\text { nantikan }\end{array}$ \\
\hline
\end{tabular}

94 NANAEKE - Indonesian Journal of Early Childhood Education, Vol. 4, No. 2, Desember 2021 


\begin{tabular}{|c|c|c|c|c|c|}
\hline & & & & $\begin{array}{l}\text { semua ku } \\
\text { nantikan } \\
\text { dirimu di } \\
\text { depan } \\
\text { kelasmu } \\
\text { menantikan } \\
\text { kami, guruku } \\
\text { tersayang } \\
\text { guruku } \\
\text { tercinta, } \\
\text { tanpamu apa } \\
\text { jadinya aku, } \\
\text { tak bisa baca } \\
\text { tulis mengenal } \\
\text { banyak hal, } \\
\text { guruku terima } \\
\text { kasihku, } \\
\text { nyatanya diri } \\
\text { ini kadang } \\
\text { buat mu } \\
\text { marah" }\end{array}$ & $\begin{array}{l}\text { dirimu di } \\
\text { depan } \\
\text { kelasmu } \\
\text { menantikan } \\
\text { kami, guruku } \\
\text { tersayang } \\
\text { guruku } \\
\text { tercinta, } \\
\text { tanpamu apa } \\
\text { jadinya aku, } \\
\text { tak bisa baca } \\
\text { tulis } \\
\text { mengenal } \\
\text { banyak hal, } \\
\text { guruku } \\
\text { terima } \\
\text { kasihku, } \\
\text { nyatanya diri } \\
\text { ini kadang } \\
\text { buat mu } \\
\text { marah", } \\
\text { sebanyak } 44 \\
\text { kata dengan } \\
\text { bantuan } \\
\text { peneliti. }\end{array}$ \\
\hline 9. & $\begin{array}{l}\text { Mengungkapkan } \\
\text { perasaan lewat } \\
\text { lirik lagu }\end{array}$ & $\begin{array}{l}\text { AR mulai } \\
\text { mengungkapkan } \\
\text { perasaan } \\
\text { dengan lagu } \\
\text { "pagiku cerahku } \\
\text { matahari } \\
\text { bersinar" }\end{array}$ & $\begin{array}{l}\text {-AR merasa } \\
\text { senang ketika } \\
\text { di putarkan } \\
\text { lagu "terima } \\
\text { kasih guruku" }\end{array}$ & $\begin{array}{l}\text {-AR merasa } \\
\text { senang } \\
\text { mendengarkan } \\
\text { lagu "terima } \\
\text { kasih guruku" } \\
\text { sambil } \\
\text { mengikuti lirik } \\
\text { lagu "pagiku } \\
\text { cerahku } \\
\text { matahari } \\
\text { bersinar ku } \\
\text { gendong tas } \\
\text { merahku } \\
\text { dipundak, } \\
\text { selamat pagi } \\
\text { semua ku } \\
\text { nantikan } \\
\text { dirimu di } \\
\text { depan }\end{array}$ & $\begin{array}{l}\text {-AR merasa } \\
\text { bahagia } \\
\text { ketika } \\
\text { diputarkan } \\
\text { lirik } \\
\text { lagu"terima } \\
\text { kasih guruku" } \\
\text { dan } \\
\text { menyebutkan } \\
\text { lirik lagu" } \\
\text { pagiku } \\
\text { cerahku } \\
\text { matahari } \\
\text { bersinar ku } \\
\text { gendong tas } \\
\text { merahku } \\
\text { dipundak, } \\
\text { selamat pagi } \\
\text { semua ku }\end{array}$ \\
\hline
\end{tabular}




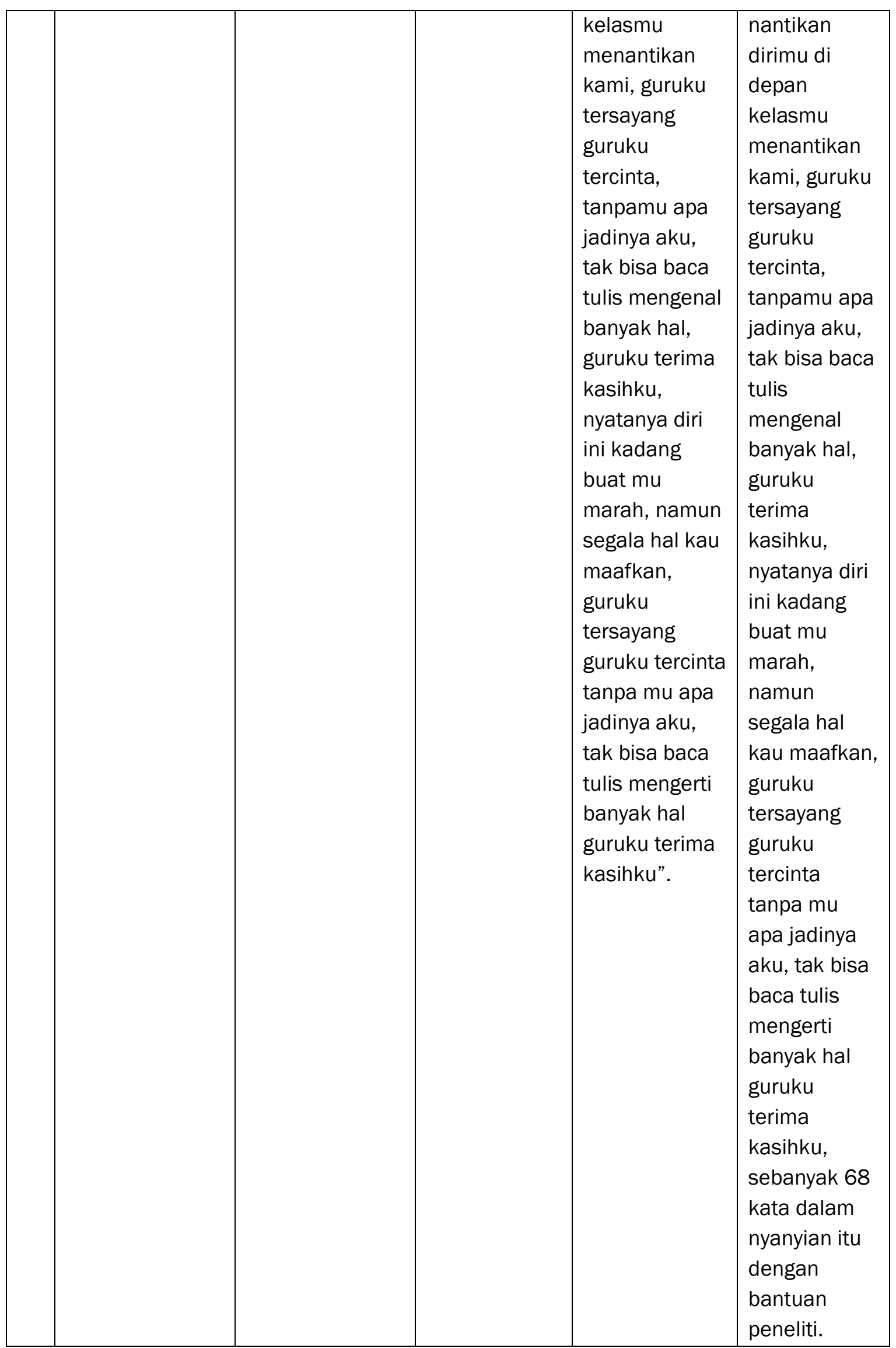

96 NANAEKE - Indonesian Journal of Early Childhood Education, Vol. 4, No. 2, Desember 2021 
Adapun ringkasan tabel hasil penelitian ini dijabarkan sebagai berikut:

\section{Perkembangan Bahasa Anak Speech Delay sebelum Penggunaan Nyanyian}

Tabel 1 pada kolom baseline A1 menunjukkan bahwa perkembangan bahasa anak speech delay sebelum penggunaan nyanyian sebanyak 19 kata yang dimiliki oleh AR sehingga berada pada kategori belum meningkat, sehingga kosakata AR masih kurang. Menurut Dr. Widodo Judarwant, Sp. A. (K) dalam Khoiriyah, Ahmad, dan Fitriani (2016) kurangnya pemerolehan kosakata yang di dapatkan oleh anak usia dini seperti dalam kasus AR disebabkan banyak faktor, mulai dari faktor biologis, psikologis maupun lingkungan di dalam dan di luar keluarganya yaitu (a) Gangguan pendengaran, (b) Kelainan organ bicara ini meliputi lidah pendek, kelainan bentuk gigi dan mandibular (rahang bawah), kelainan bibir sumbing dan lain-lain, (c) Retardasi mental, (d) Kelainan genetik, (e) Gangguan berbahasa sentral, (f) Autisme, (g) Mutisme selektif, (h) Gangguan bicara biasanya menyertai pada gangguan disfungsi otak, gejala yang terjadi sangat minimal sehingga tidak mudah untuk dikenali, (i) Alergi makanan, (j) Deprivasi lingkungan dalam keadaan ini, anak tidak mendapatkan rangsangan yang cukup dari lingkungan, baik lingkungan keluarga maupun lingkungan sekitarnya. Azizah (2017) menambahkan bahwa peningkatan jumlah anak usia dini yang mengalami keterlambatan bicara merupakan bentuk gangguan relasi dan komunikasi yang patut diwaspadai oleh para orangtua dan pendidik. Ini dapat dideteksi dari ketepatan penggunaan kata yang diucapkan oleh anak. Nantinya, penyesuaian diri anak dalam proses pembelajarannya akan sangat dipengaruhi oleh keterlambatan bicara.

\section{Perkembangan Bahasa Anak Speech Delay setelah Penggunaan Nyanyian}

Perkembangan bahasa anak speech delay setelah diterapkan penggunaan nyanyian (intervensi B) mengalami peningkatan dalam pemerolehan kosakata yaitu sebanyak 82 kata yang dimliki oleh AR sehingga berapa pada kategori meningkat, meskipun termasuk rendah untuk anak seusianya. Maka, dapat dikatakan bahwa AR mengalami keterlambatan berbicara, sebagaimana yang di ungkapkan oleh Hurlock definisi keterlambatan bicara pada anak yaitu apabila tingkat perkembangan bicara berada di bawah tingkat kualitas perkembangan bicara anak yang umumnya sama dan dapat diketahui dari ketepatan penggunaan kata (Anggraini, 2011). Penelitian yang dilakukan oleh Hidayah (2012) yang menunjukkan bahwa anak yang berada pada rentang usia 5 tahun memiliki kosakata bahasa sebanyak 1043. Sebanyak 202 kata telah diujarkan pada usia 3 tahun dan 108 kata diujarkan pada usia 4 tahun, sehingga pemerolehan kosakata pada usia 5 tahun kurang lebih sebanyak 733 kata. Sedangkan usia 6 tahun sebanyak 1414 kata yang di peroleh akan tetapi sebanyak 205 telah diujarkan pada usia 3 tahun, 122 diujarkan pada usia 4 tahun dan 241 telah di ujarkan pada usia 5 tahun, sehingga kosakata yang diperoleh oleh anak usia 6 tahun sebanyak 846 kata kata. 


\section{Peningkatan Perkembangan Bahasa Sebelum dan Sesudah Penggunaan Nyanyian terhadap Anak Speech Delay}

Setelah satu minggu penggunaan nyanyian (intervensi B), kemudian dilakukan evaluasi pada baseline A2 yang menunjukkan terdapat peningkatan perkembangan bahasa setelah penggunan nyanyian, dimana AR memperoleh kosakata sebanyak 108 kata setelah evaluasi yang sebelumnya hanya 82 kata, sehingga dapat dikategorikan meningkat. Pemerolehan kosakata menurut Jolongo (Nilawati dan Suryana, 2019) yang di dapatkan oleh anak usia 5 tahun adalah sebanyak 800 kata telah di kuasai oleh anak dan siswa Preschool usia 6 tahun diperkirakan telah belajar 6 sampai 10 kata setiap harinya. Anak pada usia ini terganggu dalam penyampaian bahasa lisannya sedangkan penerimaan bahasa dari luar sudah memadai (Isnaningsih, 2016). Begitupula yang di alami oleh AR dimana penerimaan bahasa yang di sampaikan oleh peneliti sudah baik, namun pengucapan yang dilontarkan oleh AR masih kurang jelas. Anak usia dini memiliki karakteristik yang berbeda-beda begitu juga dengan anak yang mengalami keterlambatan dalam berbicara. Hal ini didukung oleh hasil penelitian dari Wati (2018) yang memaparkan bahwa stimulasi mendengarkan lagu dan bernyanyi berpengaruh terhadap perkembangan bahasa pada anak usia dini. Penelitian tindakan kelas dari Hukmi dan Febrialismanto (2016) menambahkan bahwa sebaiknya anak diberikan kebebasan dalam memilih lagu serta cara membawakannya, sehingga perkembangan bicara anak dapat ditingkatkan melalui kegiatan yang menyenangkan. Karena anak usia dini lebih berani mengutarakan pendapat, perasaan dan mengalirkan bakatnya di bidang bernyanyi sehingga dapat meningkatkan perkembangan bahasa anak usia 5-6 tahun (Rohmawati, 2018).

\section{KESIMPULAN}

Kebaruan dari penelitian ini berfokus pada penggunaan nyanyian untuk perkembangan bahasa anak speech delay yang disusun dengan metode eksperimen single subject research berdasarkan desain penelitian A-B-A. Hal ini memudahkan peneliti dalam memahami sistematika sebab dan akibat antara variabel penelitian serta memudahkan dalam mengevaluasi kinerja dari subjek penelitian. Namun, rentan terhadap variabel pengganggu atau peristiwa kebetulan yang dapat terjadi selama proses penelitian, sehingga peneliti selanjutnya yang akan mengembangakan penelitian ini diharapkan untuk melibatkan lebih banyak narasumber agar mendapatkan informasi yang lebih akurat.

\section{DAFTAR PUSTAKA}

Anggraini, W. (2011). Keterlambatan bicara (speech delay) pada anak (studi kasus anak usia 5 tahun). In Skripsi. (http://lib.unnes.ac.id/2802/1/3489.pdf, 
diakses 1 Desember 2020).

Azizah, U. (2017). Keterlambatan Bicara dan Implikasinya dalam Pembelajaran Anak Usia Dini. Hikmah:Jurnal Pendidikan Islam (Online) Vol 6 No 2 Tahun 2017.

(https://ojs.staituankutambusai.ac.id/index.php/hikmah/article/view/60, diakses 23 September 2020).

Fauziddin, M., \& Mufarizuddin, M. (2018). Useful of Clap Hand Games for Optimalize Cogtivite Aspects in Early Childhood Education. Jurnal Obsesi: Jurnal Pendidikan Anak Usia Dini, Vol 2(2), 162. (https://obsesi.or.id/index.php/obsesi/article/view/76, diakses 24 Januari 2021).

Herlambang, Y.T. (2018). Pedagogik: Telaah Kritis IImu Pendidikan dalam Multiperspektif. Jakarta: Bumi Aksara.

Hidayah, Y.F.N. (2012), Pemerolehan Kosakata Anak Usia 3-6 Tahun di PG-TK Aisyiah Bhustanul Atfhal 25 Wage-Sidoarjo. Skripsi (Online), Fakultas IImu Budaya Universitas Airlangga (https://repository.unair.ac.id/27160/, diakses 5 Mei 2021).

Hukmi, \& Febrialismanto. (2016). Meningkatkan Kemampuan Berbicara Melalui Bernyanyi Pada Anak Usia 4-5 Tahun Di Tk Labor Universitas Riau. Educhild, Vol 5(1), (https://media.neliti.com/media/publications/165189-ID-none.pdf, diakses 18 Oktober 2019).

Hutami, E. P., \& Samsidar. (2018). Strategi Komunikasi Simbolik Speech Delay Pada Anak Usia 6 Tahun di TK Paramata Bunda Palopo. Jurnal Tunas Cendikia, Vol 1(1),

(https://ejournal.iainpalopo.ac.id/index.php/tunascendekia/article/view/384, diakses 13 Agustus 2019).

Irwantoro, N., Suryana, Y., Rohmah, M., dan Nazim. (2016). Kompetensi Pedagogik untuk Peningkatan dan Penilaian Kinerja Guru dalam Rangka Implementasi Kurikulum Nasional. Jakarta: Magenta Media

Isnaningsih, A. (2016). Pengaruh Metode Pembelajaran Bahasa Melalui Bernyanyi dan Bercerita terhadap Penguasaan Kosakata Bahasa Indonesia Anak TK ABA Seropandlingo Bantul Yogyakarta. Skripsi (Online), Fakultas IImu Pendidikan Universitas Negeri Yogyakarta (https://eprints.uny.ac.id/40356/, diakses 1 Januari 2021).

Khoiriyah, D. (2016). MODEL PENGEMBANGAN KECAKAPAN BERBAHASA ANAK YANG TERLAMBAT BERBICARA ( SPEECH DELAY ) Khoiriyah 1), Anizar Ahmad 
2) ,Dewi Fitriani 3). Model Pengembangan Kecakapan Berbahasa Anak Yang Terlambat Berbicara (Speech Delay), vol 1(1),

(https://www.neliti.com/id/publications/187403/model-pengembangankecakapan-berbahasa-anak-yang-terlambat-berbicara-speech-dela, diakses 29 Januari 2021).

Latif, M., Zukhairina, Zubaidah, R., dan Afandi, M. (2013). Orientasi Baru Pendidikan Anak Usia Dini : Teori dan Aplikasi. Jakarta: Kencana.

Lestari, P. (2016). Pengembangan Berbahasa Pada Anak Usia 4 - 5 Tahun Melalui Metode Bermain Kartu Huruf Di Tk Psm 2 Kawedanan Magetan Tahun Pelajaran 2014 / 2015. Jurnal CARE (Online), Vol 3 No 2 Tahun 2016 (http://e-journal.unipma.ac.id/index.php/JPAUD/article/view/559, diakses 16 Agustus 2020).

Morrison, G.S. (2012). Dasar-Dasar Pendidikan Anak Usia Dini (PAUD). Jakarta: PT. Indeks.

Madyawati, L. (2017). Strategi Pengembangan Bahasa Pada Anak. Jakarta: Prenadamedia Group.

Nilawati, E. dan Suryana, D. (2019). Gangguan Terlambat Bicara (Speech delay) Dan Pengaruhnya Terhadap Social Skill Anak Usia Dini. Artikel (Online), (https://www.academia.edu/35516174/GANGGUAN_TERLAMBAT_BICARA_S PEECH_DELAY_DAN_PENGARUHNYA_TERHADAP_SOCIAL_SKILL_ANAK_USIA_ DINI, diakses 28 Agustus 2020).

Nurkholis. (2013). Pendidikan Dalam Upaya Memajukan Teknologi Oleh: Nurkholis Doktor IImu Pendidikan, Alumnus Universitas Negeri Jakarta Dosen Luar Biasa Jurusan Tarbiyah STAIN Purwokerto. Vol 1(1), 24-44. (https://www.neliti.com/id/publications/104343/pendidikan-dalam-upayamemajukan-teknologi, diakses 25 Desember 2020).

Nutbrown, C. dan Clough, P. (2015). Pendidikan Anak Usia Dini: Sejarah, Filosofi, dan Pengalaman. Yogyakarta: Pustaka Pelajar.

Otto, B. (2015). Perkembangan Bahasa pada Anak Usia dini. Jakarta: Prenadamedia Group.

Puspita, A. C., Perbawani, A. A., Adriyanti, N. D., \& Sumarlam. (2019). Analisis Bahasa Lisan Pada Anak Keterlambatan Bicara. Jurnal Bahasa, Sastra, Dan Pengajarannya, vol 15(2),

(https://journal.unnes.ac.id/nju/index.php/lingua/article/download/17405/9508, diakses 7 Juli 2020).

Rasyidin, W. (2014). Pedagogik Teoretis dan Praktis. Bandung: Remaja Rosdakarya. 
Rohmawati, E. D. (2018). Peningkatkan Perkembangan Bahasa Melalui Bernyanyi Di Tk Aisyiyah Bulak Karanganyar. Skripsi (Online), Fakultas Keguruan dan IImu Pendidikan Un iversitas Muhammadiyah Surakarta (http://eprints.ums.ac.id/64512/10/naskah\%20publikasi_oke.pdf, diakses 25 November 2019).

Saat, S. dan Mania, S. (2018). Pengantar Metodologi Penelitian Panduan Bagi Peneliti Pemula. Makassar: Sibuku.

Sujiono, Y.N. (2013). Konsep Dasar Pendidikan Anak Usia Dini. E-book (Online). Jakarta: PT. Indeks

(http://sipeg.unj.ac.id/repository/upload/buku/2A_BUKU_KONSEP_DASAR_PAUD.p df, diakses 4 April 2021).

Suyadi. (2013). Teori Pembelajaran Anak Usia Dini: dalam Kajian Neurosains. Bandung: Remaja Rosdakarya.

Tilaar, H.A.R. (2015). Pedagogik Teoritis untuk Indonesia. Jakarta: Kompas.

Umah, R.Y.H. (2018). Gadget dan Speech delay Kajian Perkembangan Kemampuan Berbahasa Anak. Indonesian Journal of Islamic Early Childhood Education (Online), $\quad$ Vol $\quad 2 \quad$ No $\quad 2 \quad 2018$ (https://moraref.kemenag.go.id/documents/article/98077985952828310, diakses 31 Desember 2020).

Usman, M. (2015). Perkembangan Bahasa dalam Bermain dan Permainan (Untuk Pendidikan Anak Usia Dini). Yogyakarta: Deepublish (CV. Budi Utama).

Tsuraya, I. (2016). Kecemasan pada Orang Tua yang Memiliki Anak Terlambat Bicara (Speech Delay) di RSUD DR. M. Ashari Pemalang. Journal Psychology Universitas Negeri Semarang, Vol 1(1), Tahun 2016. (https://journal.unnes.ac.id/sju/index.php/dcp/article/view/2574, diakses 10 Oktober 2019).

Wati, N. S. (2018). Pengaruh Stimulasi Mendengarkan Lagu Dan Bernyayi Terhadap Perkembangan Berbahasa Pada Anak Usia Dini. Elementary: Jurnal IImiah Pendidikan Dasar. (Online), Vol 4 No 1 Tahun 2018

(https://e-journal.metrouniv.ac.id/index.php/elementary/article/view/1081, diakses 2 Agustus 2020).

Yasin, A., Aksu, H., Özgür, E., \& Gürbüz Özgür, B. (2017). Speech and language delay in childhood: a retrospective chart review. ENT Updates, Vol 7(1), (https://www.researchgate.net/publication/317211098_Speech_and_langua ge_delay_in_childhood_a_retrospective_chart_review, diakses 11 Januari 2021). 